\title{
Depletion of Forest Cover and Encroachment in Gonbina Reserved Forest in the Goalpara District of Assam, India
}

Dhananjoy Medhi ${ }^{+*}$ and Professor Bimal Kumar Kar ${ }^{\top}$

\begin{abstract}
Forests constitute the largest ecosystem and habitat of valuable species of plants and animals on the earth surface. The increasing size of population combined with increasing diversity of human activities is continuously degrading the forest areas of the earth's surface causing great threat to it in respect of shrinkage of coverage, loss of biodiversity and disturbance in the ecological balance. The intense depletion of forest cover in various parts has also brought about large-scale environmental changes including disappearance of many valuable floral and faunal species. In the said context, the district of Goalpara, located in the western part of Assam, was dominantly covered with dense Sal (Shorea Robusta) forest, widely distributed in both the lowland and hills of the district. However, during last few decades the dense Sal forests of the district have experienced massive depletion because of excessive exploitations and encroachments transforming many patches of forestland treeless and now being used for other purposes. Even the reserved forests are also under acute degradation and encroachment. In this paper, an attempt is made to explore the nature and dimension of forest cover change alongside massive encroachments and associated implications in Gonbina Reserved Forest of Goalpara district, Assam during 1977-2010, with the help of Survey of India toposheet, satellite imagery, field survey and Geographical Information System.
\end{abstract}

Key words: Forest, Sal (Shorea Robusta), Gonbina Reserved Forest, Satellite Imagery, Field Survey, GIS, Goalpara, Assam, India.

\footnotetext{
${ }^{+}$Assistant Professor, Department of Geography, Goalpara College, Goalpara, Assam, India, Email: dhananjoymedhi@rediffmail.com ${ }^{*}$ Corresponding Author

'̄ Head, Department of Geography, Gauhati University, Guwahati, Assam, India, Email: bimalkar@gauhati.ac.in (C)2016 Medhi and Kar. This is an Open Access article distributed under the terms of the Creative Commons Attribution License (http://creativecommons.org/licenses/by/2.0), which permits unrestricted use, distribution, and reproduction in any medium, provided the original work is properly cited.
} 


\section{Introduction}

There is a growing body of literature that recognises the importance of forests and forest covers because it constitutes a vital segment of the biosphere (Mayaux et al., 2005; Joseph, 2005; Hansen et al., 2010; Potapov et al., 2012). Forests are indeed a highly complex system of a variety of living and non-living things with predominance of trees. The key purpose of this research is to highlight the extent of desolation of forest cover and obtrusion into the Gonbina Reserved Forest, located in the Goalpara district of Assam, India. Using Geographic Information System (GIS) accompanied by the toposheet of the Survey of India, satellite imagery and field survey, the research examines the nature and dimension of forest cover change along with massive encroachments and associated implications in the Gonbina Reserved Forest for the period 1977-2010.

The research begins with a brief background outlining the importance of forests on ecosystems highlighting the fact that demographic growth continue to cause heavy loss on forest covers across the globe including India, signalling increasing damage caused to its environment and biodiversity. Following this, it describes the study area. It then goes on to discuss the methodological issues. The final section discusses the findings.

\section{Background}

Forest is extremely important for natural world as well as human beings. It is the home of much of the world's biodiversity, endangered species and indigenous human cultures. Forest also plays an important role in maintaining global ecosystems and environment at different levels. The multilateral environmental agreements on Climate Change and Biological Diversity clearly reflect the role of forest in the planet's functioning and to the human population (Mayaux et al., 2005). For humans, they have many aesthetic, recreational, economic, historical, cultural, and religious values (Joseph, 2005). Many indigenous peoples depend on forests for their livelihoods.
These valuable forests come under large-scale degradation for many centuries as a result of continuous exploitations and consequent land use change in the forest areas. The demographic expansion has caused historic loss of forest cover on the earth and most of the forestlands have become tree-less and now used for other purposes. Significant global forest cover loss is evident in all the biomes over the earth (Hansen et al., 2010). Human society in the way of development with modern technology is moving away more and more from nature and continuously imposing a great pressure on itself. The expansion of human populations, followed by forest fragmentation, forest conversion for slash-and-burn agriculture, mining operations, charcoal production, and poaching all deleteriously impact the forest resources of Democratic Republic of the Congo (Potapov et al., 2012). Similar is the case with different forest resources across the living planet.

Since the invention of agriculture, man has been in constant struggle with nature to fulfil its endless need and to extract maximum possible benefit from nature causing rapid loss of forest cover of the earth. The developments of infrastructure-for example, roads, human settlements, etc. encourage habitat loss and forest cover loss (Lambin and Geist, 2006). Encroachment of forest by individuals or ingroup expedites the forest cover loss especially in high populous nations (Iftekhar and Hoque, 2005). Originally, forest covered about 40 per cent of the total land area of the earth (Bhagabati et al., 2002). However, due to the accelerated destruction and degradation, it shrunk to about 17 per cent of the land area of the earth and now it has become a matter of grave global concern.

As per the survey of National Remote Sensing Agency (NRSA) released in 1984, the Indian subcontinent lost about 1.3 million hectares of forests every year between 1972-73 and 198081 , and this figure is continuously on the rise. As per the Government record, 22 per cent of the country's area is under forests, but satellite pictures revealed that during 1972-75, only 
16.89 per cent of the total area was under forests, which declined to 11.17 per cent during 1993-95 (Gautam, 2006). During the two decades (1975-1995), the country lost as much as 33.86 per cent of the total forest area. North East India is regarded as one of the richest forest cover regions of the country but the forest cover of the region is reducing gradually and causing great threat to the wild forest species. In an estimate of World Wildlife Fund (WWF), the north-eastern region's forest is the second richest in the world. ${ }^{1}$ The landscape of the Himalayan foothill region located on the north of the river Brahmaputra is the prime habitat for several endangered species of wild flora and fauna remarked as jewel in the crown of Indian Forests by wildlife expert Andreq Gillison (Barooah, 1979). Assam, covering a geographical area of about $78,438 \mathrm{sq}$. $\mathrm{km}$, was endowed with very rich forest with luxuriant evergreen and deciduous plants and a variety of valuable timber species such as Sal (Shorea Robusta), Gamari (Gamelina Arborea Roxb), Som (Artocarpus Chama Buch Ham), Koroi \{Albizzia Procera (Roxb) Benth\}, Titasopa (Michelia Champaca L.), etc. These rich forests came under acute depletion with loss of valuable species increasing the list of critically endangered species such as Udal (Sterculia Khasiana), Red Sandalwood (Ilex Khasiana) and Pallassen Spurge (Eupharbia Mayurnathanii). The process of deforestation is also a serious threat to the economy and future environment in the region (Bhattacharyya, 2005). As per the Economic Survey report of the Government of Assam, about 6,748 sq. km of forest area were destroyed during the period 1974-94. As per the official record, nearly 20 per cent of total geographical area of the state is under forest cover, which is far below the minimum norm of 33.3 per cent forest cover as prescribed by the National Forest Policy (Dubey, 1999). However, the remote-sensing report reveals further

\footnotetext{
1Please see, The Eastern Himalyas, WWF. Retrieved from: http://www.wwf.org.uk/where_we_work/asia/eastern_h imalayas/ and Supporting Wildlife Conservation Activities in North East India, WWF Global. Retrieved from:

http://wwf.panda.org/who_we_are/wwf_offices/india/in dex.cfm?uProjectID=IN0962
}

lower proportion of area of the state under forest cover (see, Gilbert, 2012).

So far as the Goalpara district of Assam is concerned, it was covered by dense Sal forest (Shorea Robusta) with a variety of wild floral and faunal species extending up to the foothills of Meghalaya to the south. Dr. Hamilton (1814), a British Forest Officer who had visited Goalpara, could not cross the forest at a stage because of its high density along with luxuriant growth of $\mathrm{Sal}$ trees. The forests of Goalpara formerly formed parts of the estates of various Zamindars. ${ }^{2}$ Since the acquisition of these forest areas by Government in 1955-56, considerable portion of the forests were lost due to human habitations and the increasing pressure for illegal occupation through forcible encroachments and other undesirable activities (Deka et al., 2004). Unlike the other parts of the state, Goalpara district has experienced massive degradation of forest due to exploitation of forest species and diversion of forestland for other uses. Since the last century, the forest of the district has undergone continuous degradation due to exploitation of timber, firewood, food, etc. and conversion of forestland for agriculture and settlement. Due to such large-scale deforestation, many valuable wild animals like tiger, leopard, hog deers, bisons, etc. have become extinct (Ahmed, 2007). High population growth and subsequent food requirements, shifting cultivation, illegal timber felling, forest fire, diversion of forestland and encroachment of forestland are mainly responsible to reduce the area of forests in the region even in the Reserved Forest areas. Taking these backdrops into the current research context, the next section discusses about the study area.

\section{The Study Area}

Goalpara district is located in between $25^{\circ} 28^{/} \mathrm{N}$ and $26^{\circ} 15^{\prime} \mathrm{N}$ latitudes and $89^{\circ} 42^{\prime} \mathrm{E}$ and $90^{\circ} 15^{\prime}$ $E$ longitudes being surrounded by the river Brahmaputra in the north, foothills of Meghalaya plateau in the south, river

\footnotetext{
2 Land owner who often practices on leasing his land to small farmers are called Zamindars (Bhattacharyya, 2009, 2013)
} 
Petabhokla in the east and flood plains in the west covering a total geographical area of 1,824 sq. km. As per 2011 Census data, the district has a total population of more than 1.0 million. The whole district is covered with almost flat land with scattered eroded hills and hillocks, which are part of the Meghalaya plateau. Politically, the district is bounded by the districts of Bongaigaon and Barpeta in the north; Kamrup district in the east; Meghalaya state in the south; and Dhubri district in the west. The patches of forests in the district were classified as Reserved Forest (RF) and Proposed
Reserved Forest (PRF) under the jurisdiction of Divisional Forest Office, Goalpara. Currently, there are 55 RF and 48 PRF in Goalpara district, which are under tremendous pressure of degradation and encroachment. As stated above, the research aims to assess the nature and extent of degradation and encroachment in Gonbina Reserved Forest under Goalpara Forest Range in the district. The Gonbina Reserved Forest is located between $26^{\circ} 4^{/} 57^{/ /} \mathrm{N}$ and $26^{\circ} 5 / 36^{/ /} \mathrm{N}$ latitude and $90^{\circ} 32^{\prime} 18^{/ /} \mathrm{E}$ and $90^{\circ} 33^{\prime} 40^{/ /} \mathrm{E}$ longitude covering a total area of 126.25 ha (Figure 1 ).

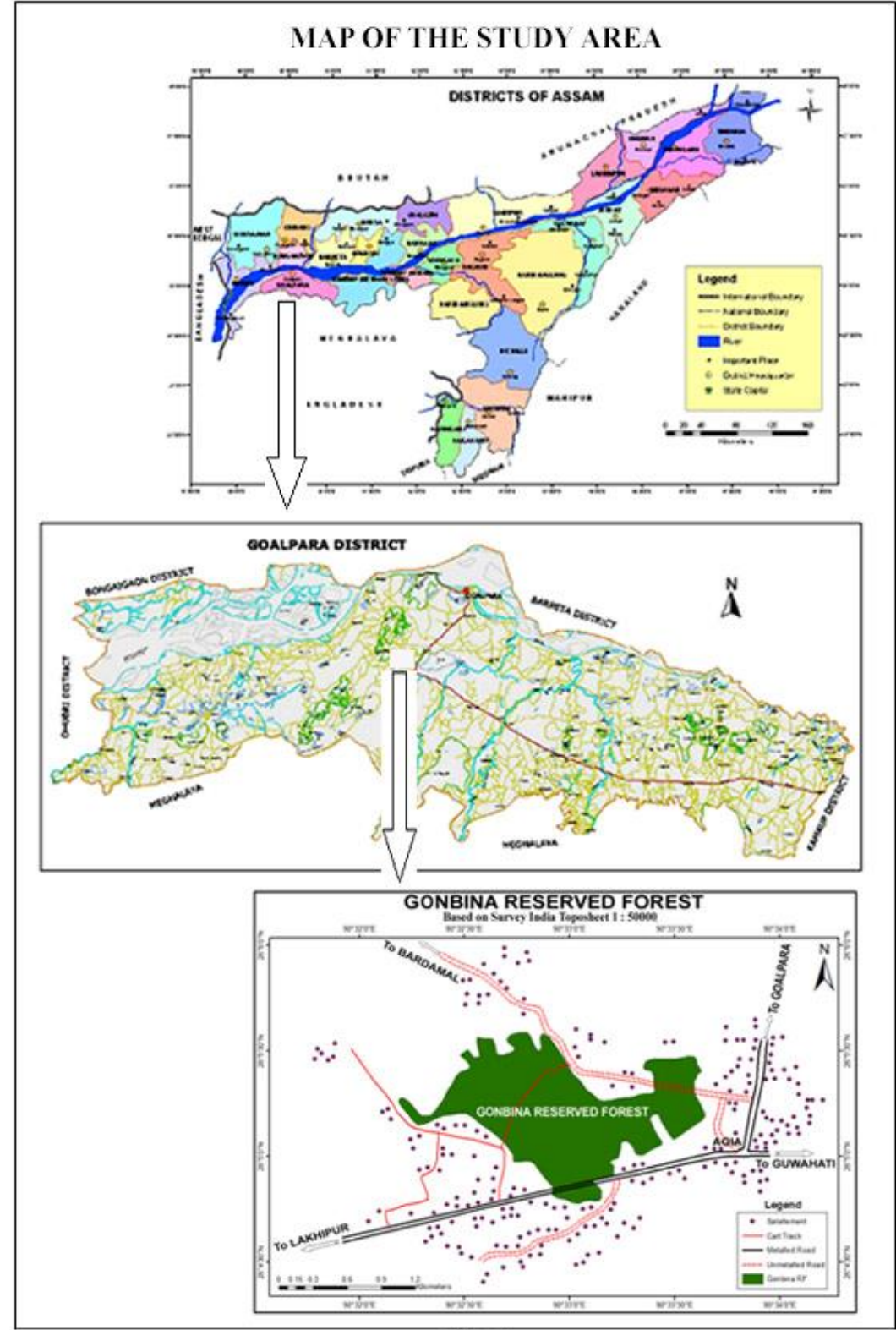

Fig. 1

Figure 1: Location of Gonbina Reserve Forest (Source: Authors) 


\section{Database and Methodology}

The study has been carried out, first, by reading literature (books and journals) on forest resources to understand the trend of degradation of forest and encroachment affecting the forest ecology. Necessary secondary data have been collected from Divisional Forest Office, Goalpara, Directorate of the Economics and Statistics, Government of Assam; Statistical Handbook, Census of India volumes and Goalpara District Gazetteer. Base map of Gonbina Reserved Forest has been prepared based on the Survey of India Toposheet No. $78 \mathrm{~J} / 12$ published by the Surveyor General of India 1972. Information regarding area under RF and PRF, boundary of R.F. and P.R.F., etc. have been collected from the Goalpara Forest Range and Protection Squad Range under Goalpara Forest Division, Goalpara. To understand the forest cover change in Gonbina Reserved Forest, satellite imagery of 1977, 1997 and 2010 have been used and mapped on the base map of Gonbina Reserved Forest. Primary data have been collected through field visit at the Gonbina Reserved Forest and through interviews with the forest guards, forest dwellers, encroachers, elderly people and people engaged in forest related activities in the area. Collected data have been processed and analysed using maps and tables.

\section{Results and Discussion}

The key purpose of this research was to explore the nature and dimension of forest cover change with an aim to probe the colossal trespassing and the associated implications in Gonbina Reserved Forest of Goalpara district, Assam during 1977-2010. The results of the research are discussed in the form of following points:

\section{Trend of Population Growth and Forest Cover Change}

The reckless exploitation of forest resources, use of forest land for other than forest purposes and encroachment of forestland for sheltering the growing population have expedited the deforestation in Goalpara district for the last few decades. As per the official record of the Divisional Forest Officer, Goalpara, out of the total area, 358.05 sq. km (19.62 per cent) area is under forest cover. However, as per the report of Assam Remote Sensing Application Centre (ARSAC) published in March 1990, the district had only 9.9 per cent area under forest cover (ASTEC, 1990). The recent satellite survey of NRSA shows deplorable condition of several protected forest areas for the whole state including the district of Goalpara. Originally as discussed above, Goalpara district was covered with luxuriant growth of Sal forest, and rich in diverse wild flora and fauna. The possible reason for deforestation is attributed to increasing population of the district mainly due to settlement of large number of refugees from former East Pakistan, immigration and infiltration from erstwhile East Pakistan (present Bangladesh) and other parts of India (Bhattacharyya, 2009; Bhakta, 1992; Taher and Ahmed, 2002). Among the RFs and PRFs of Goalpara district, all are under immense pressure causing many areas treeless. Considerable portion of the forests have been lost due to human habitation and mounting pressure of illegal occupation by means of coerced encroachments and other undesirable activities. People belonging to low economic background and dwelling in neighbouring villages, districts and flood-affected areas have migrated and encroached these forest areas. This process continues with the increase of population in the district thereby, increasing its population from 2, 16,763 in 1951 to $10,08,184$ in 2011. Since India's independence in 1947 and, especially after the formation of Bangladesh from East Pakistan, the population of Assam as well as the district of Goalpara increased at a very high rate (Table 1 ) with consequent increase in encroachment of forest areas in the district.

As noted above, Gonbina RF covers an area of 126.25 hectares. It was declared as Reserved Forest in the year 1974 vide notification No. FOR/Sett/353/61/120 dated 17-10-1974. Located just north-west of Agia, near Agia Lakhipur road, Gonbina reserve forest was 
covered with dense Sal forest and it was surrounded by built-up lands and agricultural fields. Since the last two decades, Gonbina RF has suffered from deforestation at an alarming rate with considerable encroachments in the form of roads, settlements, rubber plantations and establishments of weekly markets.

Table 1: Decadal Variation of Population in Goalpara District, 1901- 2011 (in Percentage)

\begin{tabular}{|c|c|c|c|c|c|c|c|c|c|}
\hline $\begin{array}{l}\stackrel{-}{-} \\
\text { ने } \\
\stackrel{-}{1} \\
\stackrel{-}{\circ} \\
\text { ه }\end{array}$ & $\begin{array}{l}\stackrel{-}{N} \\
\text { } \\
\stackrel{-}{1} \\
\stackrel{-}{-} \\
\stackrel{-}{-}\end{array}$ & $\begin{array}{l}\stackrel{-}{m} \\
\text { } \\
\stackrel{+}{1} \\
\stackrel{-}{\sim} \\
\stackrel{\sim}{\sim}\end{array}$ & 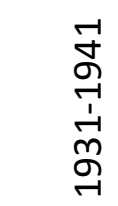 & 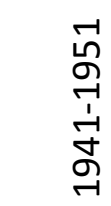 & 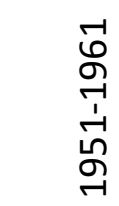 & $\begin{array}{l}\stackrel{-}{\hat{N}} \\
\text { - } \\
\stackrel{1}{1} \\
\dot{-} \\
\stackrel{-}{-}\end{array}$ & 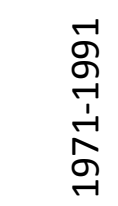 & 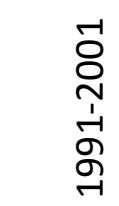 & 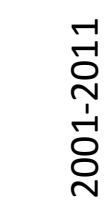 \\
\hline 29.97 & 26.92 & 15.76 & 14.83 & 9.25 & 37.10 & 45.88 & 54.12 & 23.03 & 22.74 \\
\hline
\end{tabular}

Source: Statistical Hand Book, Assam, 2012, Directorate of Economics and Statistics, Government of Assam, Guwahati

\section{Process of Degradation of Forest}

The valuable Sal species is very useful for construction of houses, furniture and different domestic and commercial items and it is widely used as fuel among the rural dwellers. In British India, Sal timber was used as railway sleepers. The economic utility of the Sal plant attracted the nearby population and in this process, the forest embracing the valuable Sal species along with other non-Sal forest species such as Gameri (Gmelina Arborea), Dudhkhuri (Holarrhena Antidysenterica), Jia (Lannea Coromondelica), etc. caused degradation of the forest of the Gonbina RF. Moreover, increase of population growth has accelerated the timber exploitation from the forest. The increasing population and growing domestic and commercial need of timber intensify the exploitation of forest species leading to acute depletion of forest cover and loss of wild animal from the Gonbina RF. Excessive timber felling, deforestation and encroachment made the Gonbina RF almost treeless with few Sal trees sprinkled hither and thither, and the rubber plants planted by the local rubber grower within the forest area leaving no space for wild fauna.

Further people dwelling in and around Gonbina RF-Agia, Balijana, Dorapara Tokorapar, Rampur, Bardamal, Fatehpur, etc. have easy access to the forest for grazing and collecting plants for domestic as well as commercial uses that led the loss of thick forest cover in the Gonbina RF. A weekly market known as Balijana Market was established initially at Balijana, but now it has extended to the area of Gonbina RF (Plates 1 \& 2).

\section{Trend of Encroachment}

Encroachment of forestland is very common in the forests of Goalpara district. In Goalpara Forest Range, out of the total area, 19.84 per cent of RF and 22.09 per cent of PRF have been under encroachment as per the report of Divisional Forest Office, Goalpara. The situation is even more alarming in Gonbina RF, where 73.66 per cent of forest area is under encroachment (Table 2). This is of course as per the 2013 data available from the Divisional Forest Office, Goalpara. In fact, the major part of Gonbina RF is occupied by rubber plantations, settlements and weekly market. Nearly 40 per cent of its total area is encroached by rubber plantation and 30 per cent by settlements. People from different villages of Goalpara district and also from some parts of Meghalaya have occupied the Gonbina RF for settlement. It is worth mentioning that Lachitnagar and Bamunjuli villages have been established within the Gonbina RF, occupied by nearly 83 and 44 households respectively (Plates 3 to 6). Most of the people are workers and are engaged in business, driving and various other services. 


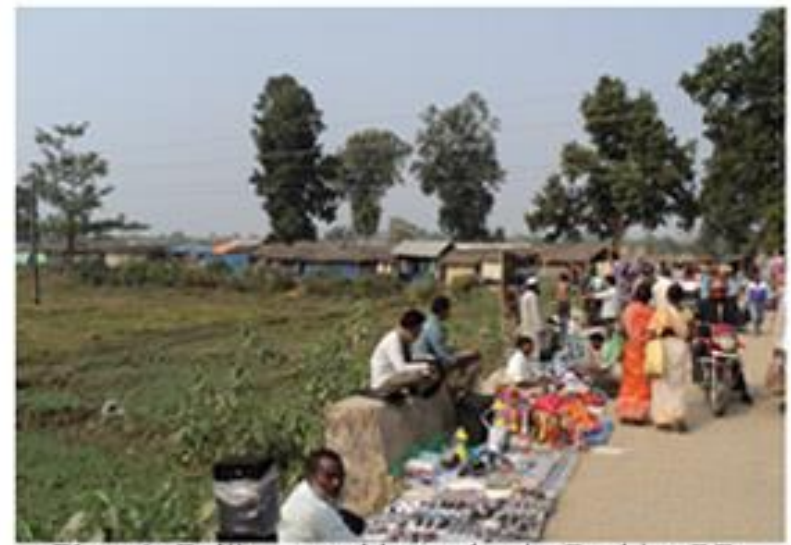

Plate 1: Balijana weekly market in Gonbina RF

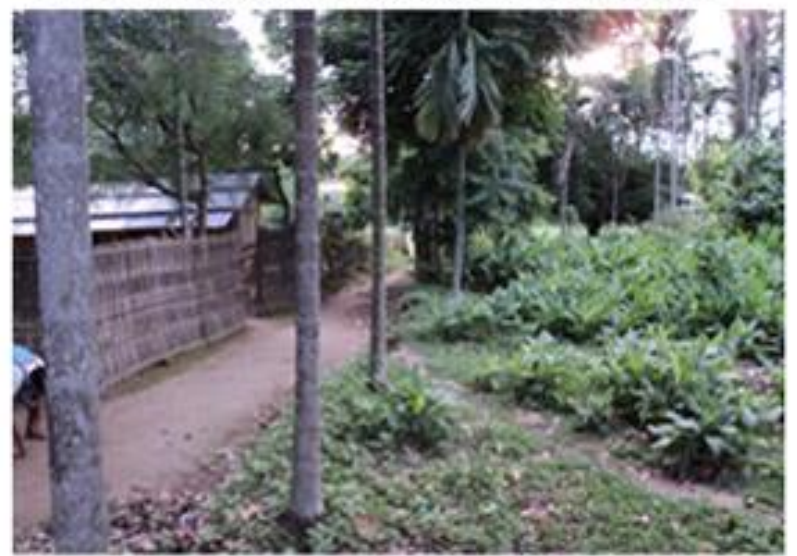

Plate 3: Rural house within RF (Lachitnagar area)

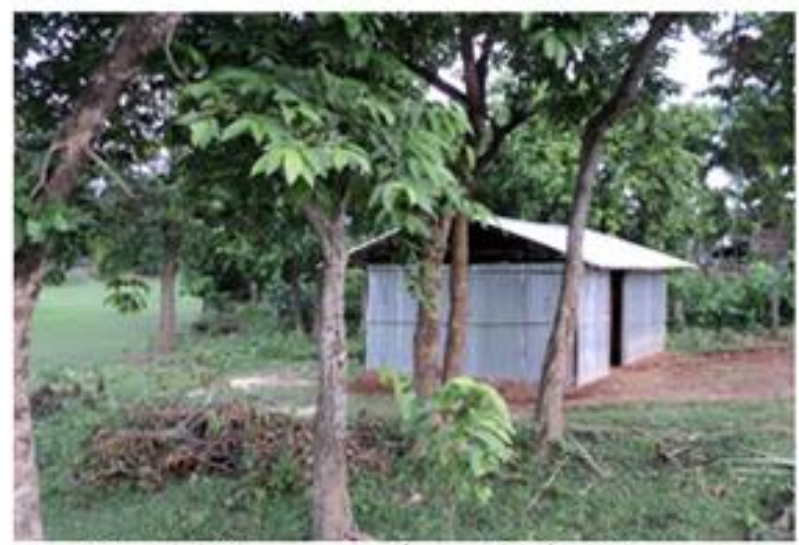

Plate 5: New encroachment in the RF

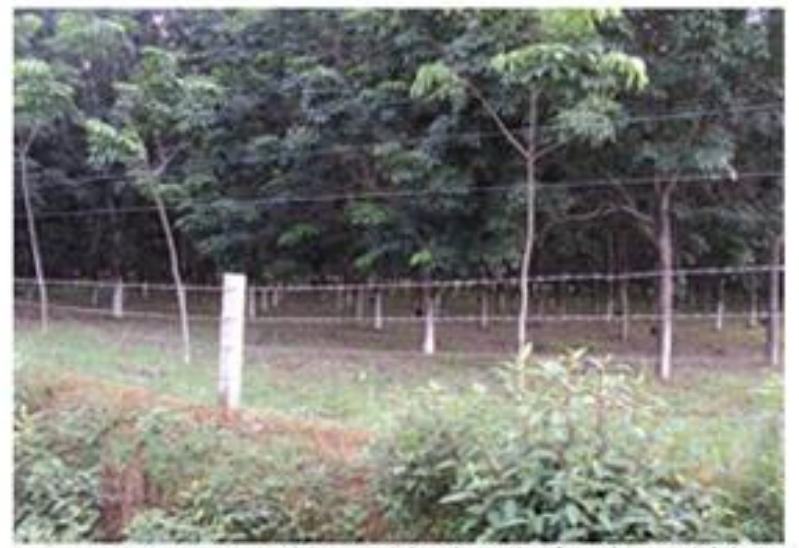

Plate 7: Mature Rubber with electric fencing within RF

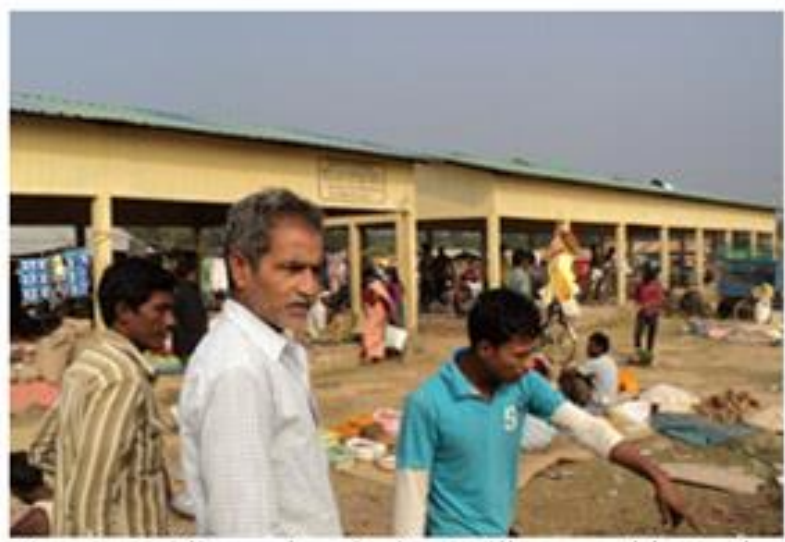

Plate 2: Public market shed at Balijana weekly market

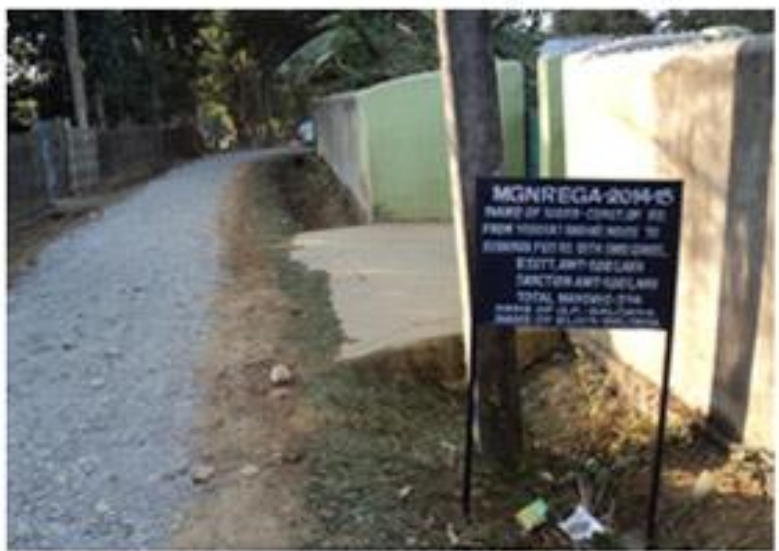

Plate 4: Rural road within RF (Lachitnagar area)

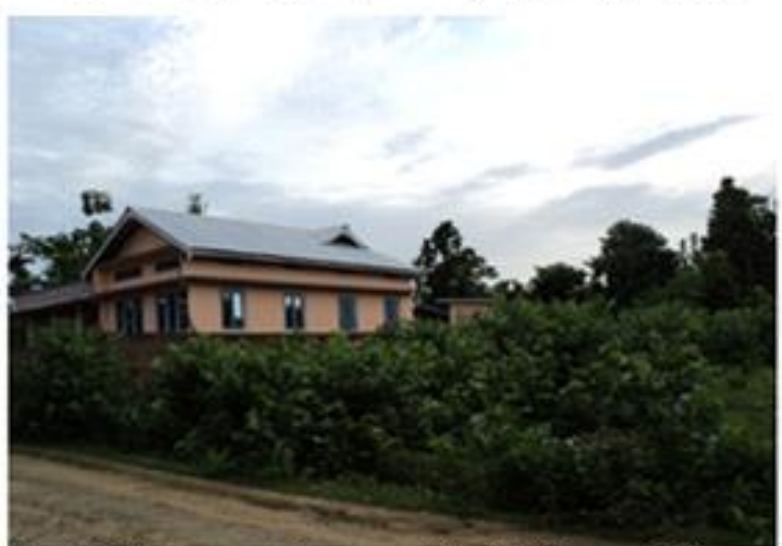

Plate 6: Permanent house within RF (Bamunjuli area)

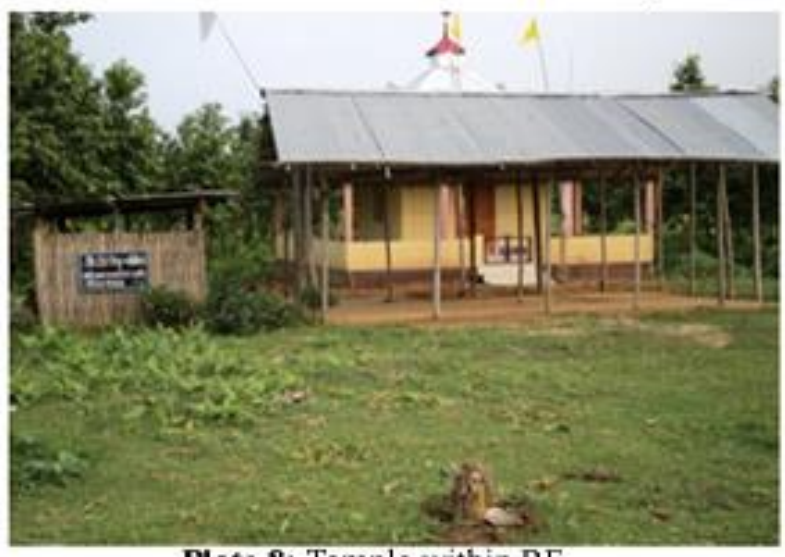

Plate 8: Temple within RF

Plates Revealing Encroachments in Gonbina Reserve Forest 
Table 2 : Area Under Encroachment in Gonbina RF, Goalpara, 2013

Total Area (in ha) Encroached Area (in ha) Encroached Area (in \%)

$\begin{array}{lll}126.25 & 93.00 & 73.66\end{array}$

Source: Divisional Forest Office, Goalpara

\section{Land Use / Land Cover Change}

As already mentioned earlier, the Gonbina RF was once covered with thick Sal forest with valuable species of flora and fauna. However, due to increasing need of growing population and modern human activities, the forest cover of the Gonbina RF has degraded more vigorously in the last two decades. The recent satellite imagery reveals that there is hardly any patch of thick forest cover, and settlements and rubber plantations have replaced the whole area. As per the Landsat MSS of the year 1977, 68.04 per cent area of Gonbina RF was under dense forest cover and now it becomes almost zero in the year 2010 (Table 3) (Figures 2 and 3). However, in 1997, an increase was shown in the vegetation cover, but it was due to inclusion of rubber growing area within the RF (Plate 7). The latest imagery shows 79.20 per cent area under degraded forest, most of which is newly occupied for rubber plantations and 20.20 per cent area under miscellaneous domestic tree plants in the settlement area. Bamunjuli, Lachitnagar, part of Dorapara, etc. are settled areas within the Gonbina RF (Plate 8). In the southern part of the Gonbina RF, a weekly market known as Balijana market operates every Tuesday.

\section{Table 3 : Land Use/Land Cover Change in Gonbina RF, 1977-2010 (Area in Percentage)}

\begin{tabular}{llll} 
Category & $\mathbf{1 9 7 7}$ & $\mathbf{1 9 9 7}$ & $\mathbf{2 0 1 0}$ \\
\hline Dense Forest & 68.04 & 66.76 & 0.60 \\
\hline Degraded Forest & 31.96 & 28.24 & 79.20 \\
\hline Plantation & 0 & 5.00 & 20.20
\end{tabular}

Source: LANDSAT MSS 1977, LANDSAT TM 1997 and P6 LIS III 2010.

\section{Contemporary Human Activities}

The area under the Gonbina RF has tremendously transformed from forest cover into habitable and plantation areas. The people living in adjacent villages expanded their holding areas intruding the forest realms of mainly Dorapara and Balijana. Inside the forests, people arriving from different nearby villages (such as Bapupara, Tokorapara, Lakhipur, Rongsai, Dwarka and Mendipathar) of Goalpara district and also from Meghalaya have settled permanently occupying significant portions of Gonbina RF. The central reason for their arrival was scarcity of land at their original localities and to avail the business opportunities and various services around Agia. It is to be noted here that Agia connects Goalpara, Lakhipur, Joleswar and Meghalaya and it is an important business hub of Goalpara district. Different commercial activities related to rubber cultivation, coal transportation from
Meghalaya to Jogighopa, and seasonal marketing of Meghalaya are being operated via Agia. The encroachers in Gonbina RF mainly depend on local commercial activities along with forest-based activity for economic support to the rural poor and flood-affected people migrated to settle in the forest areas. Most of the encroachers, as stated above, work as daily waged labour, labourers in grocery and other shops, truck labourer, thela (cart) pullar, vendor, small timber activities, and very few are in Government services.

Lack of good governance and managerial skills are the key reasons for poor protection and maintenance of the RF and PRF in the district. Due to loss of forest cover, severe conflicts have arisen from time to time between man and wild animals-elephants, monkeys, etc. This resulted in loss of life of innocent people and damage to standing crops (Talukdar and Kalita, 2014). Providing shelter to the landless 
people along with the flood victims and ethnic subsequent increase in the degradation of the conflict victims, etc. in the RF areas opens a forests.

road to more illegal encroachments and
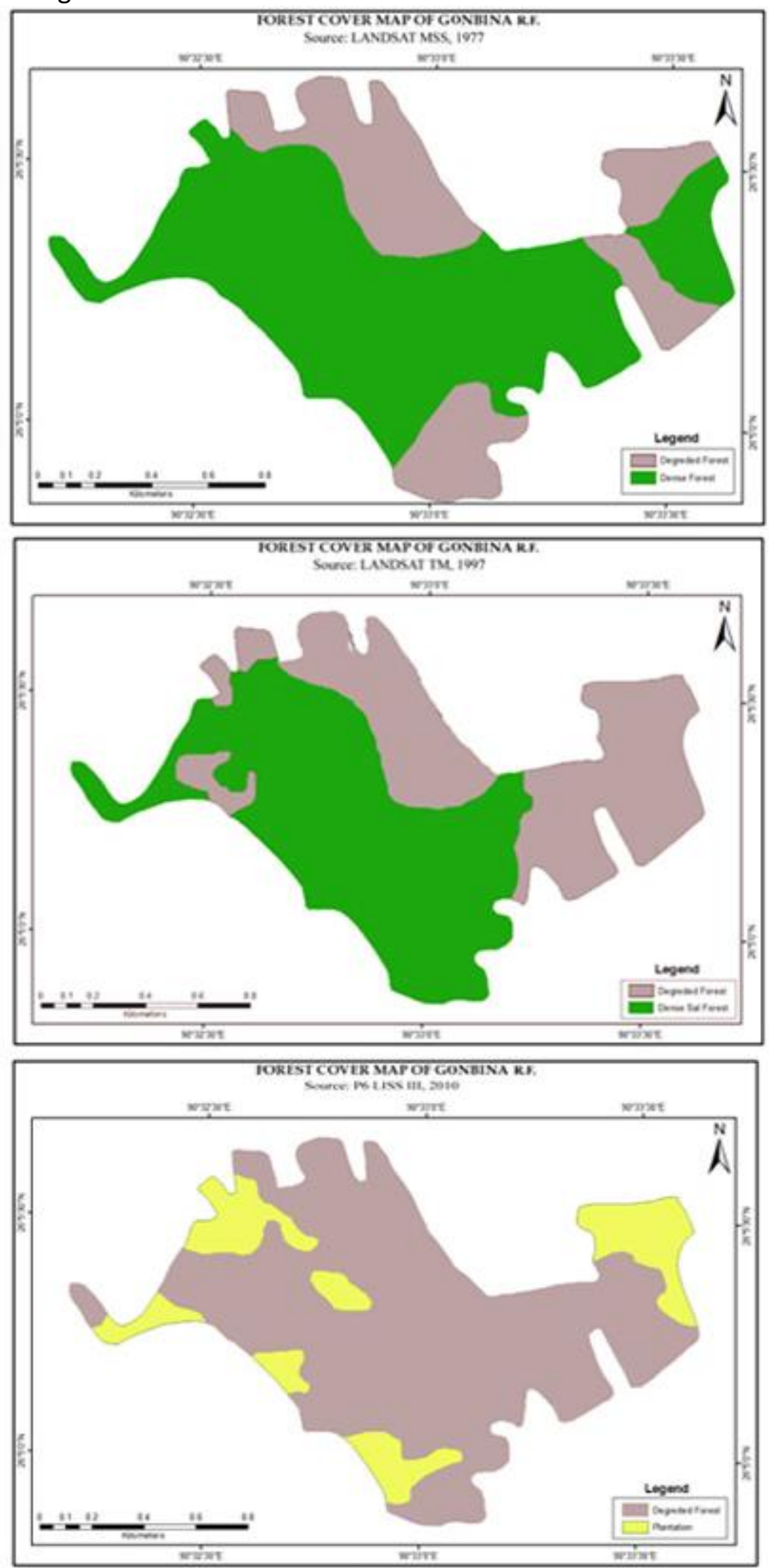

Figure 2: Trend of Change in Forest Cover of Gonbina RF, 1977-2010

(Source: Authors) 


\section{Present status of Gonbina Reserve Forest}

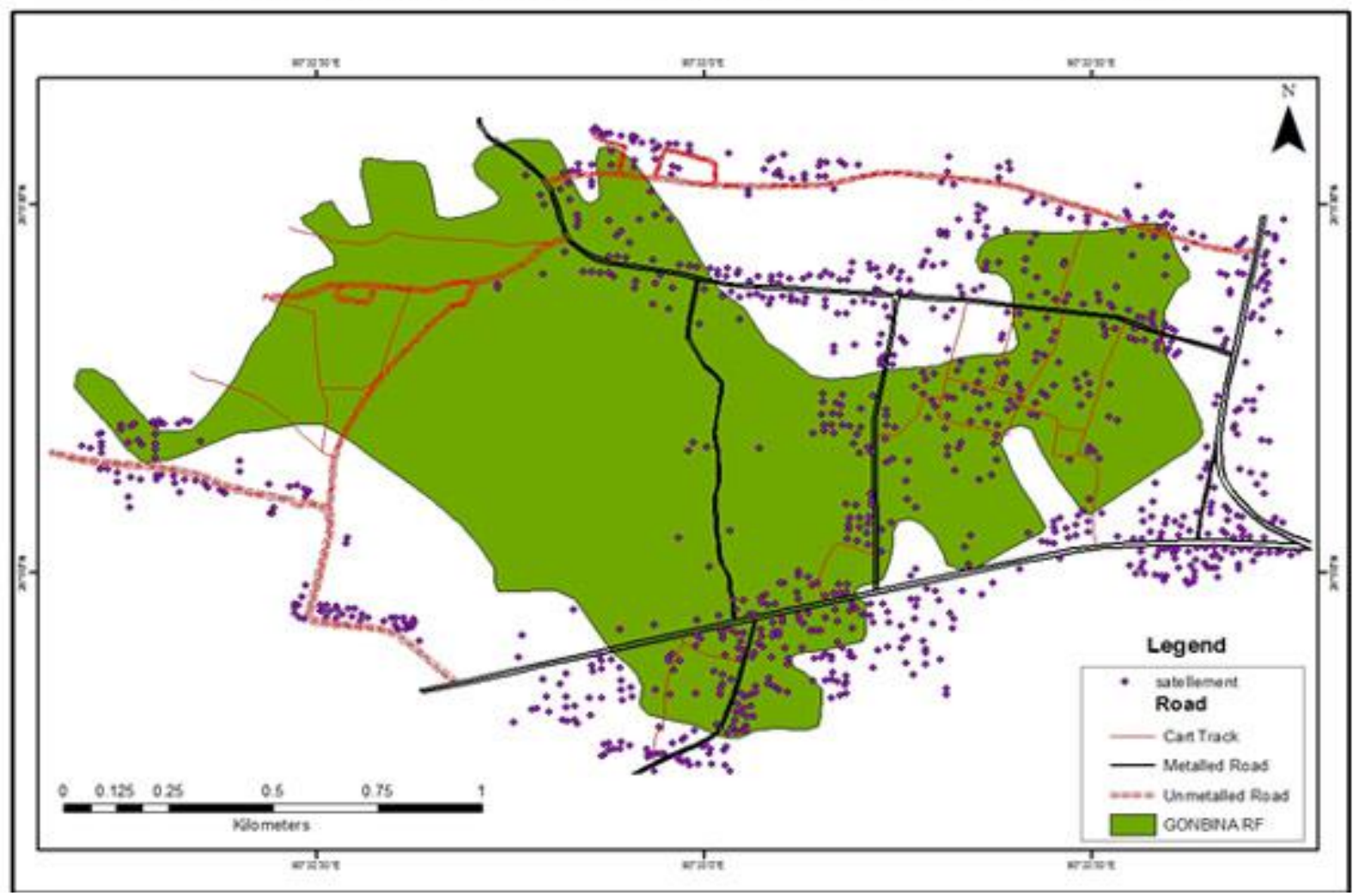

\section{Conclusion}

Forest is an inseparable part of the earth's environment and it is deeply linked to human civilisation. Similarly, Gonbina RF has an important role in the economy of the Goalpara district. However, this valuable forest cover is under continuous degradation. Goalpara district is suffering from rapid population growth due to the large-scale migration and considerably high fertility rates. Deforestation and encroachment of forestland obviously have become more vital issues of discussion in the district. Hence, it remains imperative to generate awareness among the people of the country in general including the people of Goalpara district Gonbina RF about the vulnerability of the forest. People's participation in protection of forest and wildlife is highly essential along with positive steps from the forest department. In addition, there should sustainable plans for exploitation and utilisation of the forest resources.

\section{References}

Ahmed, M. (2007). History of Deforestation and its Effect on Flora and Fauna in Goalpara District published in the Proceedings of Twentyeighth Session of North East India History Association, Goalpara.

Assam Science Technology and Environment Council (1990). District Report on Land Use/Land Cover, Goalpara District, Assam, Assam Remote Sensing Application Centre, ASTEC, Guwahati, Assam.

Barooah, D. P. (1979). Assam District Gazetteers - Goalpara District, Government. of Assam. Bhattacharyya, R. (2013). Are We Empowered? Stories of Young Indian Working women, Saarbrücken, Germany: Lap Lambert Academic Publishing, (ISBN: 978-3-659-20580-4).

Bhattacharyya, R. (2009). Examining the Changing Status and Role of Middle Class Assamese Women: Lessons from the Lives of University Students, PhD thesis, University of Newcastle upon Tyne, United Kingdom. Retrieved from: 
https://theses.ncl.ac.uk/dspace/bitstream/104 43/303/1/Bhattacharyya09.pdf.

Bhagabati, A.K., Bora, A.K. and Kar, B.K. (eds)

(2002). Geography of Assam, Rajesh

Publications, New Delhi.

Bhakta, G.P. (1992). Geography of North East India, Akashi Book Depot, Shillong.

Bhattacharyya, N. N. (2005). North East India: A Systematic Geography, Rajesh Publications, New Delhi.

Deka, S.P., Ahmed, M. and Basumatary, S.K. (2004). Deforestation Effects on Flood Level of Brahmaputra River at Goalpara Site, Assam, Environment and Ecology, 22 (spl-I), 100.

Dubey, R. M. (1999). Working Plan for Reserved Forests and Proposed Reserved Forests of Goalpara Division (1999-2000 to 2008-2009), Forest Department, Government of Assam. Gautam, A. (2006). Advanced Geography of India, Sharda Pustak Bhawan, Allahabad. Gilbert, N. (2012). India's Forest Area in Doubt, Nature, 489 (7414). Retrieved from:

http://www.nature.com/news/india-s-forestarea-in-doubt-1.11344.

Hansen, M. C., Stehman, S. V. and Potapov, P. V. (2010). Quantification of Global Forest Cover Loss, PNAS, 107 (19), 8650-8655.

Hamilton. F.B. (1814). An Account of Assam. Sreeguru Press, Maligaon, Guwahati (Reprinted).

Iftekhar, M. S. and Hoque, A. K. F. (2005). Causes of Forest Encroachment : An Analysis of Bangladesh, GeoJournal, 62(1/2), 95-106. Joseph, B. (2005). Environmental Studies, Tata McGraw-Hill Publishing Company, Limited, New Delhi.

Lambin, E. F., and Geist, H. (2006). Land-Use and Land-Cover Change: Local Processes and Global Impacts. Berlin: Springer Verlag. Mayaux, P., Holmgren, P., Achard, F., Eva, H. and Branthomme, A. (2005). Tropical Forest
Cover Change in the 1990s and Options for Future Monitoring, Philosophical Transactions, R. Soc., B. 360, 373-384.

Potapov, P. V., Turubanova, S. A., Hansen, M. C., Adusei, B., Broich, M., Altstatt, A., Mane, L., and Justice, C. O. (2012). Quantifying Forest Cover Loss in Democratic Republic of the Congo, 2000-2010, with Landsat ETM+ data, Remote Sensing of Environment, Elsevier. Taher, M. and Ahmed, P. (2002). Geography of North East India, Mani Manik Prakash, Guwahati.

Talukdar, D. R. and Kalita, B. (2014). Man-

Elephant Conflict: A Study in Goalpara District, Global Journal for Research Analysis, 3(8), 207209.

\section{Acknowledgement}

The authors gratefully acknowledge the critical comments and suggestions of the anonymous reviewers for quality improvement of the paper.

\section{About the Authors}

Dhananjoy Medhi is currently carrying out his doctoral research on "Forest-Land Encroachment in Goalpara District, Assam: A Study of its Dimensions, Causes, and Consequences" in Gauhati University. His areas of interest include Cartography, Forest \& Environment Studies.

Professor Bimal Kumar Kar is the Head of the Department of Geography, Gauhati University, Assam (India). Besides carrying out teaching, Professor Kar has been guiding M.Phil. and Ph.D. students of Geography in Gauhati University. His areas of research interest include Population, Social and Urban Geography, and Regional Development Dynamics. 